\title{
The Changing Judicial Patterns in Central Europe
}

\author{
Pre- and Post-Accession
}

\begin{abstract}
Csaba VARGa
Abstract. By the fall of Communism, also the past of Central and Eastern Europe is mostly hold eradicated, albeit it cannot but steadily survive in sublated mentality. On the field of law, this is expressed by the continuity of textcentrism in approach to law, with the law's application following the law's letters in a quasi-mechanical way. Consequently, what used to be legal nihilism in the Socialist regime has turned into the law's textual fetishism in the meantime. This is equal to saying that facing the dilemma of weighing between apparently contradictory ideals within the same Rule of Law, justice has in fact been sacrificed to the certainty in/of the law in the practical working of the judiciary. Especially, constitutional adjudication mostly works for the extension of individual rights while the state as the individuals' community is usually blocked in responding challenges in an operative manner. Situation in Poland, the Czech and Slovak Republics, Baltic Republics, as well as Croatia is surveyed through a series of case studies in order to show degrees and variations of worsening. Softening the law by activating juridical inventiveness was used to be pressed on the region during her preparation to accession, a practice that has now been counteracted by stiffening hard law anew. In either case, on the last resort, phase-lag of juridical mentality in the region may have been at stake, preserved at the stage what Western Europe could develop into when reconstruction after the end of WWII started. For post-war West's new joiners in approach and methodology - like (1) natural law considerations; (2) balancing among interests through assessing them in light of general principles and clauses, either of the law or implied by its underlying legal culture; as well as (3) constitutionalisation of issues - have remained mostly esoteric ideas, alien in mass to the region in question. The damage this condition may cause by cumulation is an added burden on the popular receptivity of catch-words heralded, among other ideals, by the Rule of Law.
\end{abstract}

Keywords: erasing the past, mechanical jurisprudence, constitutional court activism, regional phase lag, functioning as a big-organisation, Poland, Czech and Slovak Republics, the Baltics, Croatia

\section{A FRESH NEW START}

The schemes of mapping legal families had to break with the continuation of a past with the Central and Eastern European region regarded as somewhat distinct and particular, when Socialism as a regime was eradicated from the European scenario. All this looked like a magical act: as if the political downfall of a dictatorship, instituted and sustained through a Красная Армия [Red Army] imperialist occupation, were able to generate an overall change. In any case, for the present-day mapper "The 'socialist legal family' is dead and buried, and although it will take a long time to erase the traces of more than forty years of total subjection to political ideology, it seemed right to discard the chapters on socialist law." (Kötz 1998: v) This is to say that one has started waiting for some miracle again, or, otherwise expressed, for a setting of mind usual in so-called "honeymoon periods", but now missing the traces characteristic of a revolution (cf. Sorokin 1965). Such Utopianism is

Csaba Varga, Professor Emeritus, founding ex-director of the Institute for Legal Philosophy, Catholic University of Hungary (H-1428 Budapest 8, P.O. Box 6) \& Research Professor Emeritus, Institute for Legal Studies, Centre for Social Sciences, Hungarian Academy of Sciences, H-1014 Budapest, Országház u. 30; homepage: http://drcsabavarga.wordpress.com

(Received: 27.02.2014; revision received: 03.04.2014; accepted: 10.04.2014.) 
manifested by simplistic opinions, according to which, for instance, "Polish law belongs to the western legal tradition, its laws for historical and cultural reasons belonging to the Germanic and Romanistic legal families. This influence survives strongly to this day, notwithstanding a 50-year period of submission to the so-called 'socialist family' [...]. For the last sixteen years the country's laws have been in a state of constant flux, first in order to divorce, practically overnight, its 'socialist family' in favour of a marriage more proper for a market economy, and second, as soon as Poland's entry into the European Union became a feasible option, to meet the requirements of the acquis communautaire." (Stroiński 2006: 39) Under such conditions, monographic overviews and historical outlines introducing text-books on the formation of institutions can pass over half of a century without further notice; quite as if there were nothing interfering with, or interrupting, pre-WWII development. Accordingly, local institutions may elegantly be traced back to their origination in Roman law, the French revolution or interwar events, with no mention of further possible determinants which can have survived from the practice just left behind yesterday, as a proper legacy. As items belonging to such a legacy, prime mention should be done to the skill of the legal profession, thoroughly educated and socialised in the spirit of its time, that is, equipped with a mentality fully interiorised and practiced (Mańko 2007: 87). This is to say that waiting for a miracle in such a way is hardly else than the symbolic re-assertion of discontinuation itself: the gesture of clearing away the past.

No need to say that, from a theoretical point of view, such a stand is mistaken from the beginning. It presupposes mechanical understanding that reduces law to some positivated materiality or, at least, quasi-physicality (cf. Varga 2007). For instance, it would presume the mere textual building of - by institutionalising one or two further principles and provisions in - an overall regulation, in order that it can represent a brand new S1 system. It is as if law, as an instance of so called big organisations, were nothing but mere virtuality of notional aggregates, free to shape in a sheerly artificial environment, claiming treatment as a (quasi)axiomatic system. As to such breaking off continuity, only scrutiny will show that artificial eradication will have in fact used to serve nothing else than emphasising transition itself. $^{1}$

\section{WITH PAST EXTENDED}

There is a polar dynamism in the development of the European Union, defining a reverse tension between its growing expansion and the deepening of integration achieved (Bengoetxea 1993: vii). For communitarianism, equalling to dedicating some of our past property to shared purposes, necessarily induces reflexes and institutes mechanisms of selfdefence. In everyday co-existence they may wane to a considerable degree but, with the trap of (or zigzagging between) conformism and non-conformism, they tempt at doubledealing, by-pass, and pretended implementation as well.

This means that harmonisation within the European Community is fulfilled at the level of domestic law drafted and posited, but in every further respect, separation, with own interests pushed in hardly veiled competition with the rest is steadily continued. At the same time the auto-operation of the European Union - which in itself is not co-ordinated or

1 The cumulation of changes "does not mean that the former socialist countries do not form, at least temporarily, a geopolitical or legal-geographical unit. [...] The similarity, in turn, forms a new subject of comparative law, ie, the method of transformation or substitution of socialist law by new law”. (Knapp 1995: 532) 
harmonised but randomly cumulated, so chaotic to a considerable depth, when it issues accidental masses of directives and judicial statements in daily repetition, which will be somewhat acknowledged and partly also implemented, but in endless variations, by the addressee member states - generates tensions to which those addressed will react in their own manner, that is, opting for an alternative covering their own interest as drawn from their own tradition.

As to the basic setting, superimposition of Community law upon domestic regimes is like the constitutionalisation of issues: both are to pave divergent paths with concurrent and pluralising channels of reasoning. For "Directives [...] can always be invoked before national courts in order to produce a 'concurring' interpretation of national law. Their provisions can be enforced against national law when they are sufficiently clear to be directly effective, but only vis-à-vis national authorities." Moreover, "even where a real discretion has been allowed, the limits set to that discretion by Community law can in principle be invoked before the national courts" - considering the fact that "no discretion [...] can be exempt from legal review, each discretion having its limits". So, this is to say that "Indeed, Community law has to be applied by the national court, whenever it can be applied as a rule of law." (Timmermans 1979: 554, 555)

Well, old partners of the European Community have since long signalled that with the Rule of Law criterion set by the German Constitutional Court - sticking security in law, plain language, as well as guaranteeing legitimate civil expectations as a sine qua non minimum required as to fill what Rechtsstaatlichkeit presupposes ${ }^{2}-$ applied, European law would have at once collapsed. ${ }^{3}$

European law is blamed to be vague and untransparent because of the random superimposition of new and new positivations (directives and decisions) without any clear internal system and hierarchy (Bieber-Salomé 1996); ${ }^{4}$ to undermine the coherence and prevalent systemicity of domestic private law regimes (i.e., their code regulations and background doctrines) by its ad hoc character (Hommelhoff 1992: 102), as well as notional incoordination and elusive nature (Grundmann 2000), ${ }^{5}$ characteristic of the mass of incoming European interventions; to menace the stability of domestic legal regimes by the unendingly massive production of such interventions (Oppetit 1990: 3); to transform its own self, by the unmanaged simultaneous complexity and rigour of the Community's normative production, into the drawback, moreover, the problem itself, of any progress in economic development and the free movement of persons and goods, because, as established by the Commission in 1994, the hyperactive operation of the Union is blocking, by interfering with, the competitiveness of transactions performed within its reach (Burns 1997). What is more, by now disintegrative moments in, and tendencies of, the Community law and order to break it up, may overcome the impression prevailing for a half of a century,

2 BVerfGE 5 No. 7, Apothekenstoppgesetz, 1956.

3 "Luckily for all of us, the [German Constitutional] court did not repeat that particular heresy: transferred to the Community level, it would probably leave us with a very limited number of regulations that could pass the test." (Koopmans 1985: 15)

${ }^{4}$ The criticism is subsequently generalised in four directions such as "the evolutionary nature of the pillar system, the originality of the integration model, the lack of coherence in legislative production and the inaccessibility of European law". (Bieber-Amarelle 1998: 19) Facing tensions, quantitative out-put reduction through a better quality of in-put work is proposed (Piris 2004).

5 Accordingly, "the pointillistic character of such norm-generation is gradually ever more destructive of a concept of law based on the ideal of codification”. (Köbler 1993: 307) 
namely, that the law of, and the integration within, the European Union go on hand in hand (Hunt-Shaw 2009).

For the law of the European Union is like - as symbolised (Pennington 1994; Varga 2009) by - the solar system: bipolar indeed, with sun and its planetary dependents in a mutual pre-disposition, in which any non-systemic action, if strong enough, can/could explode the whole system. Each sub-system reacts in its own way, but all that notwithstanding, the overall outcome of this characteristically big-organization will be order out of chaos as a statistical average of the total motion considered. Accordingly, the mass of new impetuses the centre activates endlessly will have a definite impact with its eventually channelling and curative effect. Moreover, independently of how much all this is alien to the in-built spirit of domestic law, schemed after the past pattern of positivism, this heralds the new idealisation in sociology/anthropology as well. That is, breaking with the godly order - as generalised in Newton's causality, in which God's and humans' commands were issued and followed/transgressed in endless repetitions, now society is seen as the statistical end-product of individual moves and actions, atomised in the latter's individual contexture. And like in case of so-called Brownian motion, some orderliness will be seen in what is - microscopically observing - just mass anarchy (Reynolds 1994: 373).

From old times in legal history it is known that such reconsiderations have been usually followed by periods of consolidation. This new empiredom with five hundred millions of inhabitants in the European Union now seems to be an exception. True, there are momentous works in re of harmonisation and preparing ambitious projects directed to common codification, but their basic intention is just the opposite: instead of consolidating the law in force, they aim at expanding the Community law to growingly new terrains, not foreseen by the "pillars" of the founding Treaty of the European Union.

Member states are helpless by the inconsideration of the legal machinery of the European Union, knowing and experiencing that "Both the drafted text and the implementation of the normative message of the Union's laws risk to generate a number of islands alien to the legal system of the receptive state; and, in consequence, they hazard the internal coherence of domestic law and the laws received, and thereby also the co-ordinated operation of the system itself." (Harmathy 2001: 128) Interestingly enough, some years ago Hungarian literature urged the finalisation of the preparation (after deepened doctrinal elaboration achieved) of her new Civil Code (February 11, 2013) just as the last bastion to defend the national law's internal coherence from those constraints of the automatism of Community law implementation able to break it up, on an especially sensitive field of national existence and productive activity within the range of it.

Albeit there is no express provision obliging member-states judiciary to follow the Community interpretation and to accept the direct force of the decisions of the European Court, the state is liable for violation of Community law, provided that domestic court decision is "in manifest breach of the case law of the Court in that matter". 6

This is why it is so striking to consider the recurrent cases of the harsh openness of a member-state's self-protection, caring for national prestige and the weigh of domestic fora alike.

For instance, hardly four decades ago, one of the pioneers of the European Community idea, France, nullified an administrative court ruling in a process initiated by her minister of internal affairs, based upon the own domestic statement on the state of laws according to 
which "Directives cannot be invoked by citizens only for helping with normative grounds their objection to an individual administrative act." Moreover, such a preference of national supremacy to any Communitarian ethos was substantiated by a former Conseil d'État statement, ruling out of the "bloc of constitutionality" anything beyond the national law's boundaries, that is, beyond the criteriality exclusively relevant for assessment of norm conformism, inclusive of constitutionalism as well. ${ }^{8}$ One decade ago, the same Conseil constitutionnel [the former's successor] rejected posterior constitutional adjudication of four laws transforming European directives into domestic law, by one single - concisely drafted - argument: "the transformation of any Community directive into national law concludes from a constitutional requirement that can only be denied by another, expressedly reverse provision of the Constitution. In want of such a provision, the Community judge has exclusive competition controlling that...". 9 It is not by chance therefore that France is repeatedly and continually judged by the European Court for missing the transposition of Community directives into the domestic regime of the Code civil ${ }^{10}$ and for deepening the stigma of "national disinterest" (Nourissat 2007: 246). This sensitive relationship is not cleared up to date; or, what is more, it is not faced in depth indeed (Richards 2006).

\section{ENDING IN JURISPRUDENCE WITH PRE- AND POST-ACCESSION REQUIREMENTS HOMOLOGISED}

It is relatively rare opportunity to have reports on changes in mentality and skill of courts, the legal profession, moreover, the jurisprudence of the part of ex-Socialism, now ordinary members of the European Union. Furthermore, such reports are mostly one-sided: either self-satisfied, prophesising complete transubstantiation with no problem encountered, or fully outraged, with new generations willing to speed up overcoming belatedness. The latter's exaggeration leads to, among others, voluntary advancement of the obligation of harmonisation to a date prior to actual accession, sharply criticising authorities' lawful reaction as dated antiquity when resistance is met.

There are, of course, states which are pathological of a soci(ologic)al setting: backward, and/or belated. These are instable themselves, positioned at the crossing of transitory paths. There is a variety of them: practice may detach from manifested principles; therapy may be needed in self-protection, by making authoritarian past elements to survive; as a by- or after-effect, original intention of what to cure by instituting Rule of Law may fade away. Anyhow, the dilemma has to be faced whether law is made up simply of normative positivations just projected into the air or it is the law's environment that enforces - by

7 Conseil d'État (22 December 1978) Cohn-Bendit.

8 74-1954 DC (15 January 1975).

9 2004-496 DC (10 June 2004), considérant 7; 2004-497 DC (1 July 2004), considérant 18; 2004-498 DC (29 July 2004), considérant 4; 2004-499 DC (29 July 2004), considérant 7, published in http://www.conseil-constitutionnel.fr/conseil-constitutionnel/francais/les-decisions/acces-par-date/ decisions-depuis-1959/2004/2004-496-dc/decision-n-2004-496-dc-du-10-juin-2004.901.html.

10 C-52/00 Commission c/France, Rec. I-3827 (25 April 2002), then C-177/04 Commission c/ France, Rec. I-000 (14 March 2006). 
implementing its dynamei - order in some way. If the first option is the case, the law's genuine force (its last reserve) is weakened; in the second one, there is a proper use of the law's genuine strength, sustained by ongoing social practice.

\section{The Context}

Foundational role is usually attributed to the survival of legal positivism, mainstream organising idea that once transfigured from continental pre-WWII textual or rule-positivism into so-called Socialist normativism in the entire region. It is a syndrome called "textocentrism" that originates from it (Lętowska 1997). This is a continuation of the methodological legacy of German Pandectism, stiffened by the positivistic doctrinarism of the Muscovite style of Marxising achieved on the field of law.

As to the role of judiciary, the dated approach treating justices as mere Subsumptionsautomaten is unchanged haunting. As an apodictic sentence testified to it four and a half decades ago, "The task of the judiciary is not creation but application of legal norms, to given social relations. This holds to all kind of judiciary, including the Supreme Court as well." (Wolter 1968: 64) This explains why general provisions of law using evaluative or flexible concepts - stated as principles, value-statements or clauses - have not much chance of being referred to by the courts in the region.

Tradition is always Janus-faced. Socialist legal policy rejected Generalklauseln inserted in the German Bürgerliches Gesetzbuch (1896), for instance - as subversive Kautschukparagraphen, good only to hide "class contents" of the bourgeois law, but opening the gate for both unrestrained discretion and avoidance of the law (Szer 1962: 25). Instead, it postulated "social co-existence" as a sine qua non principle (Nowacki 1957), requiring that rights are allowed to be used according to their socio-economic purpose only. Thereby the use of rights became a function of prevailing state ideology, changing by timely needs of political interpretation of what the "message" of Marxism-Leninism should be. Or, political considerations were channelled into formal legal processes so as to be able to determine their outcome, opening gates to any option if needed. ${ }^{11}$

Over-politicisation of law was built in both the education and socialisation of the judiciary, made to harmonise with - as concluding from - their basically positivistic spirit. As a conclusion, no judge was either encouraged or prepared to thinking in principles and conflicted interests, or balancing among contrasted values. Over-politicisation as external force met the participants' internal need of individual self-protection and their pressurised self-submission in perverted forms of mechanical jurisprudence: applying law according to its letters. Such mentality pervaded administration of justice as a whole. All in all, transition from somewhere to somewhere else has remained for long just a lip service, only good for rhetorical use. ${ }^{12}$

As an effect, the sense of institutional autonomy, on the one hand, and the one of the responsibility to be borne for the decision made, on the other, equally evaporated. Soulless

11 Six decades ago, the Polish Supreme Court rejected the claim of a private owner against a state enterprise whose interest should be given priority. ŁC 495/50 (9 May 1950), published in Państwo i Prawo VI (1951) 2, 327-.

12 "The belief that in order to change the world one must first and foremost change regulations and then the rest will automatically take care of itself is an expression of similar thinking based on a belief in the magical force of the law. We have a state of law in the constitution, and so we irrevocably will also have one in life." (Lętowska-Lętowski 1996: 10) 
mass servicing in a daily routine was to substitute to the skill of balancing. Almost automatic exacting of the law became the fashion of the day, with no readiness for facing the pressure of actual challenges or use feedback channels. Outer observers, especially those sensitive to transparent forecalculability in business affairs, were only shocked to experience that with some (whatever) reference to any (relevant/irrelevant) legal provision made, decisions can be "concluded" with no convincing argumentation or justification to the depth presented; accordingly, with no indication of what exactly the normative basis for and framework of a given judgment were (Emmert 2001: 408). Or, it has to be realised again that formalism is a two-edge weapon, used also to both covering up and instigating absolutism, perhaps lurking untroubled behind.

Janus-facedness? In law? In Hungary, the hyper-activism of the formative era of constitutional adjudication may have been favourable for generating such a situation. As a matter of fact, the idol of formal legal certainty triumphed over all considerations on justice: both components (i.e., »law « and »to be ruled by«) of 'the rule of law' became emptied of morals and values, to institute in latter's place extreme zigzagging between legal nihilism and textual fetishisation - the former denied as Socialist past, but transubstantiated into the latter as full embodiment of what they understood by "the rule of law" (Varga 2008). The result was a helpless dead-end, and a speedy rush for it at the same time. Like in America, wishing more and stricter regulation, albeit one has to drown in what is at disposal already. ${ }^{13}$

Over-politicisation was maybe believed to be surpassable by reducing rule of law into autotelic, self-serving formalism. In consequence, and especially when in-built interest was provided (especially in financial matters persecuted as economic crimes), practical lawyering degenerated into search for gaps in the law. Whenever there was none, it was juridically constructed. There was no invocation to law [ius] but to the law [lex] instead; the new "rule of law" culture exhausted in finding the law, disadvantageous to the party of the case, either full of gaps or too general to get applied, and therefore unconstitutional. It ensued in effective administration and policing becoming wishful Utopianism. Any state action was rigidly made a function of some prior specification in the law. Irresponsibility for common good and evaporation of the sense of duty were to replace any organic arrangement, albeit every actor claims to this day to be busy with nothing but "defence of rights".

Albeit the meaning of 'law' itself is at stake, in terms of constitutionalism traced back to 'constitutional rule-of-law', to 'division of powers' and finally to well-operated 'checks \& balances', the above situation can be characterised as the former's practical negation: atomisation of the state's institutional network, with each partner's self-starring in rivalry for extending their relative weight and self-conceited competence, excelling by neophyte over-doing with no consideration to the merits of overall social effects, establishing, under the aegis of professional homogenisation accompanied and covered by full social and political irresponsibility, anarchy with public goods unrepresented. Accordingly, and for a while, national interest became unheard of and the nation, as such, defenceless. As to its style, mechanistic know-how technicism was to shadow the past memory of judicial Weisheit with the classical Holmes' (1881: 1) wisdom on that "The life of the law has not been logic; it has been experience."

13 Between 1990 and 1998, 894 parliamentary, 1635 governmental, and 2331 ministerial acts (all in all on 51.104 printed pages) - complemented by 501 constitutional court decisions - were issued in Hungary (Harmathy 1998: 790). 
Well, the English-American vision on how much the German Rechtsdogmatik is alienated a doctrine prognosticates the enmity by which even a German-type constitutional adjudication is received: sheer product of doctrinal erudition, where professional excellence is marked by neophytism, that is, by one master outreaching the other, and which, freed of practical considerations, will be unable to perceive the socially harmful excesses it reaches, thanks to mere intellectualism. What is lost is anything of empiricism, experience, and historical sense. In such a setting, perception of facts and contextures will have from the beginning been classified in pre-conceptualised schemes: whatever experience, intuition, sense, or emotion can only be imagined as a simplified replica of what has already been imagined and, as such, preserved in the individuals' or their generations' mental storehouse. With law, missing human environment conditioning - and conditioned by - it, justice disfigures as law-automaton, impracticable to any purpose. And a law-automaton will allow to be posited within it exclusively that what offers axiomatic proof within it: what allows to be deduced from its notional web, called Rechtsdogmatik.

The intellectual landscape is like the one of Portalis, drafter of the Code civil. When having shocked by the spirit of coming revolution, he went in exile and started sensing the danger of anti-life doctrinarism of his compatriots: outstanding intellectuals called philosophers, representing res publica. Well, what was in Germany? Small circles, neutralising one another in rivalry. In France, in contrast, salon-figures of Paris agitated, competing unendingly with one another in abstractness and excessiveness. And after all, the intellectual storm they had engendered cumulated in untempered heroes' mob actions. That is, according to his realisation already made, intellectualism with no responsibility can lead to whatever direction and cul-de-sac (Portalis 1834).

And indeed, nowadays, by the worldwide non-specified over-use of 'rule of law', it has self-emptied, unable to serve as an operative term any longer (Ekin 2011), on the one hand, standing for (as opposed and made unavailable to common sense public reason) some mysterious artificial reason, decipherable only by those initiated from the beginning, i.e., professionals of some elite whose background interest may not converge with the one of any democratic majority constituency (Conklin 1998).

The basic situation is further complicated by the fact that besides ordinary judiciary (which, after WWII in Central and Eastern Europe, petrified textual positivism that had ruled Western Europe before WWII) also constitutional courts were instituted: an activist super-forum with chances of mixed legal and political interventionism, ready to deduce a systemic network of principles from abstract terms of the constitution in order to build their own optional "invisible constitution", which is used as a freely floating meta-level law serving as a criterion in control of law-making and law-applying as well (Varga 1995). In Hungary, the constitutional court has duelled with both the parliament and the supreme court of justice in its claim of superiority, a struggle that has failed fostering either interaction or cooperation to date. This is how the supreme (in practice, the exclusive) guardian of the Rule of Law can degenerate into the factual rule of some - free floating over anything of the positive law (Vörös 1999: 68) - tyranny itself.

Czech constitutional judiciary claimed exclusive competence in deliberation on legal abstractions where international human rights instruments were at stake, by expressed fear of interference on behalf of ordinary judiciary (403/2002 Sb.), as if there was one single national body to defend - from the rest - those international interests; as if even the bodies that made such interests relevant at all in their respective country would menace the said interests. Or, "ordinary" sources of the law are to be treated by "ordinary" courts, while "non-ordinary" sources, by "non-ordinary" (constitutional) courts (Kühn 2003). One 
consequence is granted to take: in such places, European law remains alien to ordinary courts.

Albeit the European Court of Justice stated four decades ago that "where the Community authorities have, by directive, imposed on Member States the obligation to pursue a particular course of conduct, the useful effect of such an act would be weakened if individuals were prevented from relying on it before their national courts and if the latter were prevented from taking it into consideration as an element of Community law. Article 177, which empowers national courts to refer to the Court questions concerning the validity and interpretation of all acts of the Community institutions, without distinction, implies furthermore that these acts may be invoked by individuals in the national courts. It is necessary to examine, in every case, whether the nature, general scheme and wording of the provisions in question are capable of having direct effects on the relations between Member States and individuals." 14 Accordingly, in this case it was echoed that once the last resort domestic court denies control by the European one on interpretation or consideration, it may be construed as unconstitutional, with no proper judge/judging allowed.

\section{Poland}

There have been ongoing debates in Poland on the autonomy of the judiciary in general and the law-making contribution of its decision-making in particular, this latter being unchanged denied in principle albeit tolerated in practice. As to the past, there was once a supreme court guiding decision that specified state liability for a civil servant's culpable act, not provided by the then valid Civil Code Article 417. Thirty years passed, and the constitutional court, without any entitlement either, overwrote it. ${ }^{15}$ The addressee supreme court reacted to such encroaching assistance by commenting that "Albeit interpretation of legal norms by the constitutional court has no binding force for the judiciary, it can be conceded in the present case that there is no reason why to doubt the interpretation given by it."16

Clauses enacted during the time of Socialism - such as social co-existence and proper use of rights - have not been revocated or replaced, only simply re-interpreted as some normal continuation against changing times, with minor changes of shift in adaptation. Moreover, the outcome was heralded as "fundamental principles of ethical and worthy attitude", "expressing the idea of equity in law and human liberty" (Dmowski \& Rudnicki 2002: 30).

The Polish style of judicial decision-making is seen as intermediary between the French and the German ones. It can be characterised by short and categorical formulations; an establishment in which there is no distinction between questions of fact and questions of law; and doctrinal issues involved are either simplistically short-cut (like the French one) or treated in the light of scholarly opinions and previous decisions (mostly of the supreme court), analysed in order to arrive at general conclusions (like the German one). The analysis of jurisprudence is done selectively and summarised in abstract conclusions - with no interest whatever in the very facts of the given case (unlike the English one) -, serving as an alibi illustration to the decision made. From those rare references to past law (or occasionally to the French or the Italian civil codes), genuine comparison is missing. The judgment is seen as standing for the official response, excluding any idea of an alternative

14 C-41/74 Yvonne van Duyn v. Home Office (1974) ECR 1337, 12.

15 SK 18/00 Romuald K et al. v. Poland (2001), OTK Zbiór Urzędowy 8, 256.

16 IV CKN 178/01 Zbigniew S. v. Skarb Państwa et al. (2001) OSNC 7-8, 114, 117. 
solution and, of course, any dissent. Therefore justice and law are identified, concluding from the procedure itself, which is deductive, legalistic, and magisterial (Mańko 2005: 540-541). Or, "the attitude of courts is to represent a conclusion derived from the content of legal rules. The domination of arguments pro over arguments contra is one of the characteristic features of this style". (Morawski \& Zirk-Sadowski 1997: 225)

Accordingly, "one has the impression of reading the pleading for the prevailing party rather than a balanced opinion that takes all arguments into account". (Mańko 2005: 541) Its language is professional, and its conclusion is reached through lawyers' logic, with dogmas superimposed upon one another, in a depersonalised style, representing an authoritative state act and suggesting that "the law should give only one correct answer for every situation". There are some new moments, notwithstanding. For instance, "Referring to ethical and economic reasons, and to the rules of rationality or social consequences, is a popular practice." (Morawski \& Zirk-Sadowski 1997: 226) At last but not least, some more continuity in time is proven by the fact that Latin maxims are unchanged willingly quoted in judgments.

Preparation for accession was a hard time to all new member states involved, with mixed success. For instance, contemporary criticism mentions "(often incorrect and careless) translation of directives [...] often [...] word for word, thereby introducing concepts which are not known to the Polish legal system. Alternative options are omitted - even when a Directive requires a choice between them". (Czaplińsi 2001: 54)

Ordinary higher courts, however, started taking into consideration of both constitutional foundational principles and international law, even if a supreme administrative court decision (2000), quoting a European law "as the additional ground for the judgment", criticised the practical want of the harmonisation of domestic law at a preparation time when European law was not to gain legal force in Polish domestic law. ${ }^{17}$ All that notwithstanding, the constitutional court stated early enough, in $r e$ of gender equality in civil service, that "Of course, EU law has no binding force in Poland. The Constitutional Tribunal wishes, however, to emphasize the provisions of Article 68 and Article 69 of the \{Polish Association Agreement\} [...]. Poland is thereby obliged to use 'its best endeavours to ensure that future legislation is compatible with Community legislations' [...]. The Constitutional Tribunal holds that the obligation to ensure compatibility of legislation (borne, above all, by the parliament and government) results also in the obligation to interpret the existing legislation in such a way as to ensure the greatest possible degree of such compatibility."18

As a next step, soon after association had been performed, the constitutional court rejected the criticism of election to the European Parliament based on the objection of unconstitutionality of the relevant Community regulation, considering the fact that the unchanged Polish constitution grants voting rights to Polish citizens exclusively. Excluding any construction of priority or conflict between competing legal regimes, the court considered domestic constitution as "applicable directly to those structures of the Polish state exclusively through which the realisation of the interests of the republic is asserted"; stated that "domestic interpretation needs to keep the constitutional principle of assisting the European integration process and co-operation among states in mind"; paying attention

17 SAC Senago (13 March 2000), published in Polish Yearbook of International Law 24 (19992000), 217 et seq. at 219.

18 K. 15/97 in Orzecznictwo Trybunatu Konstytucyjnego (1997) 19, 380 et seq., published in East European Case Reporter of Constitutional Law 5 (1998), 271 et seq. at 284. 
to that "Instead of generating or aggravating conflicts, the law's long standing social function is their resolution." 19

Such evasion is in fact nothing but avoidance of the law. But it risks destroying the law's ethos and thereby doing more harm in the long run as compared to some apparent tactical gain, collectible in the short run.

\section{Czech/Slovak Republics}

According to critics, the once Czechoslovakia was unblended with the spirit of "revolt against formalism" (Cappelletti 1989: 9); her getting stuck at the Austrian exegesis of the end of the $19^{\text {th }}$ century meant passing by general principles of law and the express prohibition of judicial law-making. In general, "the interpretation of law was always presented as a simple cognitive operation [...and...] was always either a right or a wrong solution", that is, conclusion was reached in a static manner and as an exclusive alternative (Kühn 2004: 543). Not even implementation of human rights have shaken those simplistic patterns repeated through decades and generations. "Unfortunately, since the fall of Communism the old philosophy of bound decision-making still continues to govern the judicial discourse and has even strengthened its formalist features." For "Too often it seems that post-Communist judges hesitate to go into the merits of a case, preferring to dispose of the case on formal grounds." (Kühn 2004: 550, 555)

Only their constitutional court challenged the underlying situation - in a struggle with the country's supreme court, by the way -, nullifying a normative act, for instance, as it was "proven to be shiningly contradicting (owing to over-formalism) the principle of justice". ${ }^{20}$ As if constitutional adjudication as such was to transmit a message to administration of justice by ordinary courts, claiming that they are not "absolutely bound by the literal wording of a legal provision, as they can and must deviate therefrom if such a deviation is demanded by serious reasons of the law's purpose, the history of its adoption, systematic reasons or any principle deriving from the constitutionally conforming legal order. [...] In doing so, it is necessary to avoid arbitrariness; the court decisions must be based on a rational argumentation". ${ }^{21}$ Accordingly, if wrongs are to be cured, then all it has to mean that "legal enactments cannot be interpreted so dogmatically and non-conformably to the constitution as to de facto give rise [...] to new injustices". ${ }^{22}$ Otherwise speaking, it presupposes, while also concluding therefrom, that "legal enactments do, and must always, include within themselves the principles recognized as part of the democratic states governed by the rule of law". ${ }^{23}$ Otherwise, it cannot be but a case of "mechanical application of the law [...that...] - whether disregarding the rationale and meaning of the legal norm intentionally or by ignorance - makes from the law an instrument of alienation and absurdity". ${ }^{24}$

The president of the republic himself emphasised the need for a value-centred judicial decision-making. In the senate, at the occasion of the procedure for a constitutional judge

19 K 15/04 (31 May 2005): 1 \& III.2, published in Orzecsznictwie Trybunału Konstytucyjnego Zbiór urzędowy, A, 5, 47, 655-668: 34, 10; 34, 9 (Kühn 2005: 573-574).

20 ÚS 15, 17, III. dec., ÚS 224/98.

21 ÚS 7 (1997), 87, Pl. dec., ÚS 21/96 (Kühn 2011: 200-201).

22 ÚS 3 (1995), 227, IV. ÚS 215/94 (Kühn 2011: 202).

23 ÚS 6 (1996), 249, IV. dec., ÚS 275/96 (Kühn 2011: 201).

24 ÚS 9, 399, Pl. dec., ÚS 33/97 (Kühn 2011: 201). 
nomination, he reclaimed that what is now prevailing "is mechanical, I would like to say senseless, application of law, which almost becomes an object of some cult. [...] It is an approach toward the application of law which does not permit any control by ordinary common sense; nor does it allow for any consideration for the law's sense, meaning or circumstances, any consideration of the probable legislative intent or even the core of law's value in a hard case. Although the law is a human product, it attains almost metaphysical authority". 25

Such was the basic situation the fact notwithstanding that the preparation to association was unprecedented in its rush ahead. Preceding the obligation of direct Union law application, for instance, the Olomouc high court rejected the Skoda Auto motion ignoring the European competition law regulation by declaring that "free market and especially antitrust law are [...] usually enriched by external law, which is an absolute necessity in the perspective of the harmonisation of laws of the European Community and the Czech Republic". ${ }^{26}$ As a next step, the constitutional court re-affirmed the identity of values and basic principles of both the European Union Act of Accession and the own constitution. Within some years - before the association had been performed and with direct reference to a European Court decision ${ }^{27}$ - it was confirmed that "Primary Community law is not foreign law for the Constitutional Court, but to a wide degree it penetrates into the Court's decision making - particularly in the form of general principles of European law."28

At the same time, however - applying correctly the domestic law in force, half a decade before the European law should have had direct force - the supreme court declined reconsidering a contractual issue upon the plaintiff's reference to good faith, as understood in Western Europe and the European Community. As it was explained, "validity of the agreement made [...] must be decided according to the then valid law, as both lower courts did. In contrast, laws and directives valid in the countries of the European Community are not applicable, as the Czech Republic was not (and still is not) a member of the Community, and that is why the Czech Republic is not bound by these laws. The binding force of the rules to which the appellant refers cannot be inferred from any provision of the $\{$ Czech Association Agreement $\}$, as the court of appeal concluded. The question of harmonization of legal practice of the Czech Republic with legal practice of the European Community is gaining in, but this cannot change anything in the outcome of this case". ${ }^{29}$ Before accession - and, conformingly, "considering the present phase of the European integration" Slovakia's supreme court also resisted the direct application of a European directive. ${ }^{30}$

25 Václav Havel in ČTK (14 March 2002) (Kühn 2011: 227).

26 2A6/96 (14 November 1996) in Právni rozhledy 5 (1997) 9, 484-.

27 C-179/90 Merci convenzionali porto di Genova SpA v. Siderurgica Gabrielli SpA (1991) ECR I-5889.

28 410/2001 Re Milk Quota, electronically available at: www.concourt.cz (Kühn 2005: 567$568)$.

2925 Cdo 314/99 (12 December 2000), electronically available at: www.nsoud.cz.

30 76/2000 (25 August 1999), published in Zbierka stanovísk Najvyššieho súdu a rozhodnutí súdov Slovenskej republiky 4 (2000), 55. 


\section{Baltic Republics}

Critical overviews report on judicial practice narrowly and inflexibly following the letter of the law. There was no place for active judicial mentality, sensitively weighing and balancing, as well as complementing and adapting the law, under the all-Soviet sun.

For instance, the Estonian civil code (1965) had no clause of good faith. As a matter of fact, it was only introduced by the $1^{\text {st }}$ Paragraph, Article 108, of the new code's general part - in force from 1 September 1994 - as a provision tentatively generating new jurisprudence step by step, which became visible by the turn of the Millennium only (Krull 2000: 122). At the same time, unjustified enrichment is not posited in the code, so there is no caveat referring to it either. Not even their supreme court is toiling with general principles of law, so - as a typically American commercial lawyer was led to remark that - what prevailed there was "an extreme form of legal positivism [...which...] may result in unjust rulings or even a complete denial of justice". (Emmert 2001: 406)

As to the relationship between European law and domestic law during the pre- and the post-accession phase, it is reported that judicial fora in Lithuania took into consideration, as an instance guiding judicial interpretation, European provisions regarding competition and copyright law well before her association. At the same time, however, the normative foundations of direct application have not been cleared up enough. Accordingly, preaccession practice has continued further on more or less unchanged, transforming the earlier pattern into a retroactive one (Goldammer \& Matulionytė 2006: 270).

As to Estonia, the supreme court is said to frequently deny both preliminary questions to be addressed to the European Court and the European law to be applied in constitutional adjudication. In that respect, a formal justification is usually forwarded and in a most logical manner, according to which there is no domestic competence for doing so, regarding that neither the constitution nor the European community law has any relevant provision. ${ }^{31}$

The situation in Latvia and Lithuania is even more clear-cut as European statistics have not known about preliminary questions forwarded from these new member states.

\section{Croatia}

Croatia is self-characterised as a specimen of legal culture expressedly positivistic and formalistic, identified with the pattern within which law is conceived of, and treated as, a self-fulfilling end to be taken in itself.

It is striking even in a Central European perspective that courts there have never raised the issue of the laws' constitutionality; judgments are not published; case law is unknown; and in want of any form of law-reporting, past and present judicial decisions are not reflected or commented upon by anyone. Concludingly, those taking part in the everyday administration of justice do not consider themselves either professionally or sociologically competent to role-play an expert offering de lege lata or de lege ferenda opinions merging on law in force, as if there were not, and could not even be, reverse link from lawapplication to law-making (Ćapeta 2005).

Before a case is decided on the last resort - a chance that may take several years in consequence of chronically long delays - any public word on them would qualify, as undue interference, a specified crime. ${ }^{32}$

31 3-4-1-1-05 (4 November 2006) (Ginter 2006: 919).

32 Croatian criminal code (Narode novine 110/1997, resp. 111/2003), section 309. 
At the same time, however, the Croatian constitutional court is rather active in enforcing the European Convention of Human Rights. Domestic law conflicting to whatever international agreement is sanctioned as a violation of the principle of the rule of law, henceforth the very idea of conflict is rejected as it could only qualify as unconstitutional. ${ }^{33}$

True, professionals in Croatia know that any option for an accelerated path of development needs certain caution. For, especially in law, instruments and institutionalisations can prove to be a two-edge weapon. The very personality of justices who are "liberated" from traditional professional limitations through the reduction of their old patterns of rigorous argumentation and justification to a licence of creative invention at please, may have negative repercussion that, in want of sufficient tradition in the background, will remain hard to control by sheerly normative regulative means. Gospić town court, in a genocide case, established the fact, for instance, that "Serbs have happened to murder Croats for half a millennium". ${ }^{34}$ Well, such a legacy is obviously setting back the development of judicial ingenuity, a circumstance that, as a counter effect, may give a place to the upvaluation of practical lawyers' skill and ingenuity, especially in hard cases.

Phases lag? Belatedness? All this may at most be relative, a function of the adopted point of view. As a by-effect, they can easily turn to become expressedly positive, by preserving skills and sensitivities which may be especially useful at a time when other cultures will leave them behind. For instance, "Thus, paradoxically, the positivism and formalism of Eastern European judges may sometimes make them 'good European judges', i.e. judges who faithfully apply Community law" - in contrast to present-day mostly standardised Western European practice which is apt to question (as an issue of validity or effect) the basis, legitimation, or field of operation, of the provisions to be applied of the European law (Ćapeta 2005: 16).

\section{PERSPECTIVES}

The variety of practices relating to the new - once Socialist - members of the European Union induces reconsideration. For the association agreements themselves (taken de lege lata, i.e., without a critical - de lege ferenda - view of the chance of their improper preparation) have in no case foreseen harmonisation of domestic and EU laws to be enforced when justice is administered preceding the time of the legal act of actual joining, so all those divergences notwithstanding, their variety may have rightly covered the original intention of both parties. Moreover, enforcing anticipatory harmonisation of the normative grounds of domestic judicial decision-making with no due authorisation in its underlying (valid) law could only be a neophyte over-fulfilment within the process of association, with the negative side effect (overshadowing the short run gain of early adaptation) that it may have in fact impaired the sine qua non absolutism of the very idea of the Rule of Law and, as a part of it, legal certainty, thereby also debilitating, in a paradoxical manner, the idea of constitutionalism, too, which had once been expected to substantiate the entire undertaking as the upmost reason for change at all.

The foundational realisation is that the European Union is marching on and further on in time as a characteristic big organisation after our region's accession as well. Accordingly, it seldom recourses to issuing directly applicable and enforceable provisions and detailed 
regulations drafted within some well-ordained normative framework, save specific emergencies. In average cases, it entrusts the progress of effective integration to the workings of its big structure and total motion, as well as the mutuality between the EU and its member states, which, well-tried, already has stood the test of time, that is, the skill of how to manage tensions and their resolution, which are necessarily to form in the process. That is, the organisational idea, apparatus and technicality conceived of as the chance of having an "order out of chaos" has been proven the most successful enterprise the humanity has ever erected and experienced in its long - and known - history (Varga 2009).

The European law - alongside with the overwhelming mass of the judicial acquis communautaire - gains normative force for the countries joined from the Central and Eastern European region from May 2004 on; this is clearly stated by the Act of Accession (Article 2) and sanctioned by the European Court: "From the date of accession".

There is a moment of impatience and subjective exaggeration in the fact that local professional literature treats the issue of pre-accession observance/non-observance of European law by local domestic courts in terms of persuasive force (traditional in the American precedential regime, used to distinguish the former from the precedents' expressedly binding force), only in order to vilify the genuinely law-abiding pattern of those judicial fora which reject mixing, in their legal procedure, what is considered to be law and what is simply non-law (or, perhaps the promise of some future law at the most) at a given place and time, criticising, for instance, cases where preference is given to the application of the official law as "directly effective" valid normative ground, instead of something airy - at least, to some, persuasive, according to personal tastes - soft law (Týć 2001: 231). Albeit all such instances, bourgeoning in the region in question, can only exemplify on the final analysis nothing else than disintegration of discipline, bounds and traditions of the legal profession, moreover, at a momentous time when its underlying legal culture is to face inorganic transfer of a mass of external laws. For, as it is known, in cultures of Civil Law exclusively what is made normative (formally valid) by a directly effective source of the law (and promulgated accordingly) can at all be enforced in the name of law. And what can be termed 'persuasive' is simply non-law in a Civil Law system, knowing no precedents and no softening processes either, able to replace - by breaking through - the idea of systemic building in both deduction and justification.

To arrogate as binding anything at most 'persuasive' is contradictio in adiecto from the beginning, far from "isolationism" in itself, with which it is far too often accused. For the situation is clear: the legislator could do anything but refraine actually from doing that. Its odium, if there is one, must not be transferred to the judiciary. It is ironical to teach, in a process of transitioning from a dictatorship, without scruples again that in a state where courts are powered to entitle themselves to initiate any path to take, independently of whether or not their initiative is covered - justified and legitimated - by the law, well, that such unbound discretion will necessarily turn to become creative in all directions, generating legal uncertainty on borderline of sheer despotism. This is next to judgeocracy stricto sensu, where any genuine "checks \& balances" within the division of powers is already waned away (Hirschl 2004; also the Czech President Václas Klaus in Loužek 2006). Thereby such instances of pioneering post-modernists' fundamentalism, also derived by the mainstream catch-word "constitutionalism", raises doubt in that whether constitutionalism has at a definite meaning, usable as an operative term, or not (cf. Fallon 1997).

As is known, not even Community law provides express ordering for the topic. Three decades ago, the European Court stated in general (and in a way irrelevant for those in the process of association still) in re of a somewhat analogical issue that "Although in general 
the principle of legal certainty precludes a Community measure from taking effect from a point in time before its publication, it may exceptionally be otherwise where the purpose to be achieved so demands and where the legitimate expectations of those concerned are duly respected" 35 And, to be sure, Community law has no category of "those awaiting, and preparing for, association" or "those learning, and preparing for, the EU law". In addition to their specific Act of Accession, common regulation concerns their activity as well. Accordingly, one may state that what is particular and also detrimental in the region's contemporary development is by far not revolving around whether or not transition process is hustle and runs ahead, passing over limitations set by domestic law, but the region's overall belatedness, that is, its too late detachment - providing that it has happened at all and has been crowned with success at all - from the Soviet-type Communism once imposed upon it.

This is also to say that in addition to individual success by which a sophisticated or crude variety of "dictatorship of the proletariat" subdued the particular legal regime to follow imported patterns, what really matters is the added - secondary - effect: the phaseslag of judicial methodology. For, while Muscovite Marxism petrified "bourgeois" legal positivism of the first part of the $20^{\text {th }}$ century, the countries in question became necessarily deprived of Western professional re-orientation in the meantime: (1) post-WWII moral renaissance, (2) criteriality of natural law (with the "nature of things"), (3) fertilisation of practice by general clauses and principles, as well as with concern for human rights, and (4) the constitutionalisation of issues. Accordingly, the gap to be bridged is not so much the one between the pre-World War II period and contemporary law but the one between own past, preserved in professional memory, of last pre-WWII democratic achievements and postWWII Western continental judicial patterns and methodologies, reshaped in the meantime.

This haunts today and will continue haunting in our near common future as well. Concludingly, for a given period the region's legal culture will feature some otherness within the European Union. Moreover, as adapted locally, also Community law and integration will have, in local adaptation/materialisation, some regional determination.

All this comes true without the law of the European Union foreseeing or authorising anything like to occur. But the path to be covered is a great challenge indeed, and it is only viable if backed by proper dedication. Also it is to be remembered that any exigency of following external patterns may be accompanied, as usual corollary, by both longing for perfection and inertia, keeping the organicity of local pasts somewhat alive - with the chance of laziness as well, with remnants traceable also in big moves.

Or, eventually, there is one job to perform: transcending past by both bringing its historical account and promising perspectives for such a venture. It should not to be a l'art pour l'art programme nor mere praying-mill repetition of a mantra, able to generate magic effect somehow. There is a common future to be built in common, with all professions involved. Providing that it would fail, added burdens might dislocate the process. It could deprive the whole process of perspectives, bringing down participation in one common Europe a sheer formalism. 


\section{REFERENCES}

\section{Authors}

Bengoetxea, J. (1993): The Legal Reasoning of the European Court of Justice. Towards a European Jurisprudence. Oxford: Clarendon Press.

Bieber, R.-Amarelle, C. (1998): Simplification of European Law. Columbia Journal of European Law 5: $15-37$.

Bieber, R.- Salomé, I. (1996): Hierarchy of Norms in European Law. Common Market Law Review 33: 907-930.

Burns, T. (1997): Law Reform in the European Communities and its Limits. Yearbook of European Law 16: 254-265.

Ćapeta, T. (2005): Courts, Legal Culture and EU Enlargement. Croatian Yearbook of European Law and Policy I: 1-21.

Cappelletti, M. (1989): The Judicial Process in Comparative Perspective. Oxford: Clarendon Press.

Conklin, W. A. (1998): The Phenomenology of Modern Legal Discourse. The Judicial Production and the Disclosure of Suffering. Aldershot, etc.: Ashgate.

Czaplińsi, W. (2001): Harmonisation of Laws in the European Community and Approximation of Polish Legislation to Community Law. Polish Yearbook of International Law 25, 45-.

Dmowski, St.-Rudnicki, St. (2002): Komentarz do kodeksu cywilnego [Commentary to the Civil Code], I. Wyd. 4. Warszawa: Wydawnictwo Prawnicze LexisNexis.

Ekins, R. (ed.) (2011): Modern Challenges to the Rule of Law. Wellington: LexisNexis.

Emmert, F. (2001): The Independence of Judges: A Concept often Misunderstood in Central and Eastern Europe. European Journal of Law Reform 3: 405-409.

Fallon, R. H., Jr. (1997): "The Rule of Law" as a Concept in Constitutional Discourse. Columbia Law Review 97: 1-56.

Ginter, C. (2006): Constitutional Review and EC Law in Estonia. European Law Review 31: 912-923.

Goldammer, Y.- Matulionyte, E. (2006): The Application of European Union Law in Lithuania. European Law Review 31: 260-270.

Grundmann, S. (ed.) (2000): Systembildung und Systemlücken in Kerngebieten des Europäisches Privatrechts. Gesellschafts-, Arbeits- und Schulvertragrecht. Tübingen: Siebeck Mohr.

Harmathy, A. (1998): Codification in a Period of Transition. University of California Davis Law Review 31: 783-798.

Harmathy, A. (2001): Jogrendszerünk átalakulása és az Európai Unió joga [The Transformation of Hungarian Legal Order and the Law of the European Union]. In: Ius privatum - Ius commune Europae Liber Amicorum. Studia Ferenc Mádl dedicata. Budapest: ELTE ÁJK Nemzetközi Magánjogi Tanszék 125-134.

Hirschl, R. (2004): Toward Juristocracy. The Origins and Consequences of the New Constitutionalism. Cambridge (Mass.), London: Harvard University Press.

Holmes, O. W., Jr. (1881): The Common Law. Boston: Little, Brown \& Co.

Hommelhoff, P. (1992): Zivilrecht unter dem Einfluß europäischer Rechtsangleichung. Archiv für die civilistische Praxis 192: 71-107.

Hunt, J.-Shaw, J. (2009): Fairy Tale of Luxembourg? Reflections on Law and Legal Scholarship in European Integration. Electronic copy available at: https://www.researchgate.net/ publication/251331735_Fairy_Tale_of_Luxembourg_Reflections_on_Law_and_Legal_ Scholarship_in_European_Integration.

Knapp, V. (1995): Comparative Law and the Fall of Communism. Parker School Journal of East European Law 2: 525-.

Koopmans, T. (1985): Europe and its Lawyers in 1984. Common Market Law Review 22: 9-18.

Kötz, H. (1998): Preface to the Third Edition. In: Konrad Zweigert, K.-Kötz, H. Introduction to Comparative Law. $3^{\text {rd }}$ rev. ed. Oxford: Clarendon Press.

Krull, I. (2000): Legal Integration and Reforms: Innovation and Traditions. Juridica International [Tartu] V: 119-123.

Kübler, F. (1993): Traumpfade oder Holzwege nach Europa? Oder: Was wir uns von der Rechtsgeschichte wünschen sollten. Rechtshistorisches Journal 12: 307-314. 
Kühn, Z. (2003): Application of European Law in Central European Candidate Countries. European Law Review 28: 551-560.

Kühn, Z. (2004): Worlds Apart: Western and Central European Judicial Culture at the Onset of the European Enlargement. The American Journal of Comparative Law 52: 531-567.

Kühn, Z. (2005): The Application of European Law in the New Member States: Several (Early) Predictions. German Law Journal 6: 563-582. Electronic copy available at: http://www. germanlawjournal.com/pdfs/Vo106No03/PDF_Vol_06_No_03_563-582_Articles_Kuhn.pdf.

Kühn, Z. (2011): The Judiciary in Central and Eastern Europe. Mechanical Jurisprudence in Transformation? Leiden, Boston: Martinus Nijhoff.

Łętowska, E. (1997): The Barriers of Polish Legal Thinking in the Perspective of European Integration. Yearbook of Polish European Studies I: 56-.

Łętowska, E.-Lętowski, J. (1996): Poland Towards to the Rule of Law. Warsaw: Wydawnictwo Naukowe Scholar.

Loužek, M. (ed.) (2006): Soudcokracie v ČV. Fikce nebo realita? [Judgeocracy in the Czech Republic: Fiction or Reality?] Praha: CEP.

Mańko, R. (2005): The Culture of Private Law in Central Europe after Enlargement: A Polish Perspective. European Law Journal 11: 527-548.

Mańko, R. (2007): Is the Socialist Legal Tradition "Dead and Buried"? The Continuity of Certain Elements of Socialist Legal Culture in Polish Civil Procedure. In: Wilhelmsson, T.-Paulino, E.Pohjolainen, A. (eds.): Private Law and the Many Cultures of Europe. Alphen aan den Rijn: Kluwer Law International, 83-103.

Morawski, L.-Zirk-Sadowski, M. (1997): Precedent in Poland. In: MacCormick, D. N.-Summers, R. S. (ed.): Interpreting Precedent. A Comparative Study. Ashgate: Dartmouth, 219-258.

Nourissat, C. (2007):'La jurisprudence de la Cour de justice des Communautés européennes: Un regard privatiste à partir de l'actualité. Archives de Philosophie du Droit 50: 245-259.

Nowacki, J. (1957): Niektóre zagadnienia zasad współżycia społecznego [Some Issues of Social CoExistence Required]. Państwo i Prawo XII/7-8: 99-.

Oppetit, B. (1990): L'expérience française de codification en matière commerciale. Recueil Dalloz, Chronique: $1-$.

Pennington, K. (1994): Learned Law, Droit Savant, Gelehrtes Recht: The Tyranny of a Concept. Syracuse Journal of International Law and Commerce 20: 205-215.

Piris, J.-C. (2004): The Legal Orders of the European Union and of the Member States: Peculiarities and Influences in Drafting. European Journal of Law Reform 6: 1-14.

Portalis, J.-É.-M. (1834): De l'usage et de l'abus de l'esprit philosophique durant le XVIII siècle. $3^{\mathrm{e}}$ éd. Paris: Moutardier.

Reynolds, N. B. (1994): Rule of Law in Legal and Economic Theory. In: Kotsiris, L.E. (ed.): Law at the Turn of the Twentieth Century. Thessaloniki: Sakkoulas, 357-376.

Richards, C. (2006): The Supremacy of Community Law in France. European Law Review 31: 499517.

Rodin, S. (2002): Main Accents in Practice of the Constitutional Court (1991-2001). In: Croatian Judiciary. Lessons and Perspectives. Zagreb: Croatian Helsinki Committe for Human Rights \& Netherlands Helsinki Committee, 219-268.

Sorokin, P. A. (1925): The Sociology of Revolution. Philadelphia, London: J. B. Lippincott.

Stroiński, R. (2006): Report from Poland. European Company Law 3: 39-.

Szer, S. (1962): Prawo cywilne. Część ogólna [Civil Law: General Part]. Wyd. 3 Warszawa: Wydawnictwo Prawnicze.

Timmermans, C. W. A. (1979): Directives: Their Effect within the National Legal Systems. Common Market Law Review 16: 533-555.

Týć, V. (2001): Czech Republik. In: Ott, A.-Inglis, K. (eds.): Handbook on European Enlargement. A Commentary on the Enlargement Process. The Hague: T.M.C. Asser Press, 229-238.

Varga, Cs. (1995): Transition to Rule of Law. On the Democratic Transformation in Hungary. Budapest: ELTE “Comparative Legal Cultures" Project.

Varga, Cs. (2007): Reception of Legal Patterns in a Globalising Age. In: López Calera, N. (ed.): Globalization, Law and Economy. Proceedings of the 22 ${ }^{\text {nd }}$ IVR World Congress, IV. Stuttgart: Franz Steiner Verlag, 85-96. 
Varga, Cs. (2008): Transition? To Rule of Law? Constitutionalism and Transitional Justice Challenged in Central \& Eastern Europe. Pomáz: Kráter.

Varga, Cs. (2009): Legal Theorising: An Unrecognised Need for Practicing the European Law. Acta Juridica Hungarica 50: 415-458.

Vörös, I. (1999): "kevesebb lesz az elegáns röpködés a jogrendszer fölött" ["There will be less elegant flying to and fro above the legal system"]. (Interview by Halmai, G.-Tordai, Cs.) Fundamentum No. 2: 60-66.

Wolter, A. (1968): Prawo cywilne. Zaryís częśći ogólnej. [Civil Law, General Part]. Wyd. 2. Warszawa: Państwowe Wydawnictwo Naukowe 1968.

\section{Legislation}

Croatian criminal code (Narode novine 110/1997, resp. 111/2003)

\section{Jurisprudence}

$E U$

C-41/74 Yvonne van Duyn v. Home Office (1974) ECR 1337

C-98/78 Racke v. Hauptzollamt Mainz (1979) ECR 69

C-99/78 Decker v. Hauptzollamt Landau (1979) ECR 101

C-179/90 Merci convenzionali porto di Genova SpA v. Siderurgica Gabrielli SpA (1991) ECR I-5889

C-52/00 Commission c/France, Rec. I-3827 (25 April 2002) / C-177/04 Commission c/ France, Rec.

I-000 (14 March 2006)

C-224/01 Köbler (2003) ECR I-10239

\section{Croatia}

U-I-920/1955 \& U-I-950/1966 (15 July 1998) (Narodne novine 41/1998)

No. I KŽ 862/03-8 (29 January 2004)

No. I KŽ 862/03-8 (29 January 2004)

\section{Czech Republik}

ÚS 3 (1995), 227, IV. ÚS 215/94

ÚS 6 (1996), 249, IV. dec., ÚS 275/96

2A6/96 (14 November 1996), published in Právni rozhledy 5 (1997) 9, 484-

ÚS 7 (1997), 87, Pl. dec., ÚS 21/96

ÚS 9, 399, Pl. dec., ÚS 33/97

ÚS 15, 17, III. dec., ÚS 224/98

25 Cdo 314/99 (12 December 2000), published in www.nsoud.cz

410/2001 Re Milk Quota, published in www.concourt.cz

\section{Estonia}

3-4-1-1-05 (4 November 2006)

France

74-1954 DC (15 January 1975)

Conseil d'État (22 December 1978) Cohn-Bendit

2004-496 DC (10 June 2004), considérant 7 / 2004-497 DC (1 July 2004), considérant 18 / 2004-498

DC (29 July 2004), considérant 4 / 2004-499 DC (29 July 2004), considérant 7

Germany

BVerfGE 5 No. 7, Apothekenstoppgesetz, 1956

Poland

ŁC 495/50 (9 May 1950)

K. 15/97 Orzecznictwo Trybunatu Konstytucyjnego (1997) 19, 380, published in East European Case Reporter of Constitutional Law 5 (1998), 271- 
SAC Senago (13 March 2000), published in Polish Yearbook of International Law 24 (1999-2000) 217-

IV CKN 178/01 Zbigniew S. v. Skarb Państwa et al. (2001) OSNC 7-8, 114

SK 18/00 Romuald K et al. v. Poland (2001), OTK Zbiór Urzędowy 8, 256

K 15/04 (31 May 2005), published in Orzecsznictwie Trybunatu Konstytucyjnego Zbiór urzędowy, A, $5,47,655-668$

\section{Slovakia}

76/2000 (25 August 1999), published in Zbierka stanovísk Najvyššieho súdu a rozhodnutí súdov Slovenskej republiky 4 (2000), 55- 